\title{
Right predilection of lung cancer, does it affect oncologic outcome?
}

\section{Akciğer kanserinin sağ yerleşimli olma eğilimi onkolojik sonuçları etkiler mi?}

\author{
Suheyla Aytac Arslan', İpek Pinar Aral'², Gonca Altınışık İnan ${ }^{1}$, Havva Karabuga1, Sedef Açıkgöz ${ }^{1}$, İlhami \\ Ünal $^{1}$, Fatma Altıntaş ${ }^{1}$, Selcan Tekin ${ }^{1}$, Hüseyin Furkan Öztürk ${ }^{1}$, Yilmaz Tezcan ${ }^{1}$ \\ ${ }^{1}$ Ankara Atatürk Eğitim Araştırma Hastanesi \\ ${ }^{2}$ Elazı ̆ Fethi Sekin Şehir Hastanesi
}

Dergiye Ulaşma Tarihi:17.12.2018 Dergiye Kabul Tarihi:05.04.2019 Doi: 10.5505/aot.2019.01488

\begin{abstract}
ÖZET
GÍRIŞ̧ ve AMAÇ: Akciğer kanseri (AK) en sık görülen malignitedir ve hala kanser ölümlerinin önde gelen nedenlerinden biridir.Bu çalışmanın amacı, sigara kullanımının ile tümör lokalizasyonu, prognoz ve akut yan etki üzerindeki etkisini değerlendirmektir.

YÖNTEM ve GEREÇLER: Ankara Atatürk Eğitim Araştırma Hastanesi'nde akciğer kanseri tanısıyla 24.11.11-14.9.16 tarihleri arasında küratif torasik radyoterapi verilen 72 hasta retrospektif olarak değerlendirildi. Primer sonlanım noktaları, akut yan etki ve genel sağkalımdır (OS).

BULGULAR: Altmış beş hasta (\% 90,3) erkek, yedi (\% 9,7) kadındı. Tümör lokalizasyonu sağ tarafta\% 62,5, solda\% 37.5 idi. Hastaların\% 62.5'inde eşzamanlı kemoterapi uygulanmıştı. Ortanca takip süresi 22 aydır. Sağ akciğer kanseri, KHDAK'de sigara içen hastalarda sol akciğere göre daha yüksek iken (p0,05), bu oran KHAK'de anlamlı değildi (p0,5). Ayrıca tüm grupta yaş arttıkça sol akciğer lokalizasyonunda bir artış vardı (p0,2). KHDAK'de akut yan etkiler sağ akciğerde daha şiddetlidir ( $\mathrm{p}<0,043)$. KHDAK grubunda, ARP, 50'den fazla sigara içen 5 hastanın hepsinde gelişti ve bu oran, 50 yıldan az bir süre sigara içen hastalara göre anlamlı derecede yüksekti (p0.044). KHDAK hastalarında ARP sağ akciğerde belirgin olarak daha fazladır (p0,05), ancak KHAK'de anlamlı fark yoktu $(p=0,1)$. OS'de sağ ve sol akciğer kanseri arasında bir anlamı farklılık yoktur.

TARTIŞMA ve SONUÇ: AK sağ akciğerde daha sık görülür. Benzer şekilde, akut pulmoner yan etkiler de KHDAK'de sağ tarafta daha sık gözlenmektedir. Genel sağkalımda anatomik lokalizasyona göre anlamlı farklılık yoktur.
\end{abstract}

Anahtar Kelimeler: Akciğer Kanseri, Anatomik Lokalizasyon, Yan etki, Prognoz, Radyoterapi

\begin{abstract}
INTRODUCTION: Lung cancer (LC) is the most common malignities and still remain the leading cause of cancer deaths. The aims of this study are to assess the effect of cigarette smoking on the localization and effect of the location of tumors on the prognosis and acute adverse effects.

METHODS: 72 patients that given curative thoracic radiotherapy between 24.11.11-14.9.16 in Ankara Atatürk Educational Research Hospital with diagnosed lung cancer were evaluated, retrospectively. Patients diagnosed with LC and underwent curative radiotherapy (RT) were included. Primer endpoints are the acute adverse effect and overall survey (OS).

RESULTS: Sixty-five patients $(\% 90,3)$, were male and seven $(\% 9,7)$ were female. Tumor localization was $62,5 \%$ on the right side and $37.5 \%$ on the left side. $62.5 \%$ of the patients had concurrent chemotherapy. Median follow-up is 2 years. While the right lung cancer was significantly higher in patients who smoked in NSCLC than in the left lung (p0,05), this ratio was not significant in SCLC (p0,5). There is also an increase in left lung localization with increasing age in all group $(\mathrm{p} 0,2)$. Acute side effects in NSCLC are more severe in the right lung (p0,043). In the NSCLC group, ARP developed in all 5 patients who smoked more than 50 pct and this ratio is significantly higher than in patients who smoke less than 50 pct year (p0,044). ARP in NSCLC patients is significantly more common in the right lung $(\mathrm{p} 0,05)$ but there was no significant difference in SCLC (p 0,1). There are no statistically difference in OS between right and left lung cancer.
\end{abstract}

DISCUSSION AND CONCLUSION: LC is often seen in the right lung. Similarly, the acute pulmonary side effects are also more frequently observed on the right side in NSLC. There are no statistically difference in OS between right and left lung cancer.

Keywords: Lung cancer, Anatomical localization, Side Effect, Prognosis, Radiotherapy 


\section{INTRODUCTION}

Lung cancer is one of the most common malignancy and is still remains the leading cause of cancer deaths in the world. Tobacco is a major risk factor in the development of lung cancer and active and/or passive tobacco exposure is associated with $85 \%$ to $90 \%$ of cases (1). A dose-response relationship exists between tobacco smoking and the risk of developing lung cancer so that tobacco sensation lead to decrease in cancer related deaths (1). Median age is 70 years and $80 \%$ $85 \%$ of cases are NSCLC. Post-mortem series revealed that lung cancer frequently occurs in the right upper lobe than left lower lobe (2).

The trachea starts below the cricoid cartilage and reach to the carina and bifurcates into right and left main bronchi where about the level of the fourth thoracic vertebra (3). The angle of right main stem bronchus is usually smaller than the angle of the left main stem bronchus which causes foreign body aspiration into the right lung more than left (4). Like foreign body, carcinogens may also accumulate more on the right side so that right side lung cancer is more common than the left.

Some studies explained this nonuniform distribution with 'Contact hypothesis' (2). This hypothesis advocated that ciliary motion was inhibited by smoking which cause destroying of the mucociliary clearance and leading to accumulation of the carcinogens on the surface of bronchial epithelium. Due to anatomical differences, this harmful effect was more seen on the right side.

There is a limited number of studies evaluating the effect of this difference on the treatment and outcomes. The aim of this study is to evaluate the relationship between tumor localization and oncologic outcome of patients with lung cancer.

\section{MATERIAL METHOD}

72 patients diagnosed with lung cancer received curative thoracic radiotherapy (RT) between 24.11.11-14.9.16 in Ankara Atatürk Educational Research Hospital were evaluated retrospectively. Patient files and data from the electronic system were used for the study. Patient demographics, tumour localization, stage, chemotherapy protocols, dose-volume histograms, acute and chronic side effects, treatment response and final status were noted.

According to AJCC, patients with stage 1-4 small cell and non-small cell nonsmall cell lung cancer were included. Patients with the missing information and aged under 18 years were excluded. The RTOG / EORTC Radiation Morbidity Scoring Scheme was used for acute side effects.

\section{Statistics}

Analyses were performed using SPSS ver 20 . Overall survival (OS), and Disease-free survival (DFS) were calculated from the first day of RT. The first event definitions were death from any cause for OS and relapse or death for DFS. Kaplan-Meier methods were used to obtain estimates of anatomical distributions. Log-rank tests were used to evaluate the univariate effect. To test significant associations between tumour side and frequency/survival, the Kruskal-Wallis analysis followed by the U Mann- Whitney test was applied. p-values $\leq 0.05$ were considered significant.

\section{RESULTS}

72 patients with primary LC were analysed; 65 patients $(\% 90,3)$ were male and seven $(\% 9,7)$ were female. Dyspnea and cough were the most common presenting symptoms $(n=29$, $41 \% ; n=2840 \%$ ) and only $4 \%$ of the patients were asymptomatic. The most common comorbidity was the cardiovascular illness with a rate of $34 \%$ and $33 \%$ of patients have no co-morbidities at all. Tumor localization was $62,5 \%$ on the right side and $37,5 \%$ of the patient on the left side. $73 \%$ of the patients were $\mathrm{T} 2-3$ and $29,2 \%$ of the patients were SCLC. Two of third patients had concurrent chemotherapy. The most common concurrent chemotherapy is weekly $50 \mathrm{mg} / \mathrm{m} 2$ cisplatin. The rate of smoking was $71 \%$ and $92 \%$ among women and men, respectively. Patients' clinical characteristics are listed in table 1. Median follow-up was 22 (range, ) months. Median dose was 60 Gy (range, 10-66 Gy), median PTV volume was 399 cc (range, 100$1081 \mathrm{cc}$ ), median GTV volume was $399 \mathrm{cc}$ (range, 16-613 cc).

Median survival (MS) was 28.6 (range, 8,4-40) months. Median DFS was 22.5 months. 
The median survival was 30.6 (range, 22-39) months vs 28 (range,13-40) months in nonsmokers and smokers respectively (p: 0,62 ) (Figure 1). Similarly, smoking does not significantly effect on DFS (p: 0,9).

Smokers had significantly high incidence of right-side NSCLC $(\mathrm{p}<0,05)$ (figure2), but they don't have a side tendency for SCLC (p:0,5). There is also an increase in left lung localization with increasing age in the whole group (p: 0,2) (Figure 2). Acute side effects were observed in $72 \%$ of the patients. The most common side effect was grade 1 dysphagia. Acute side effects in NSCLC were more severe in the right lung (p:0,043) (Figure 3 ). Patients who developed ARP had a median 49 pack-year cigarette use and who did not develop ARP had 28 pack-year cigarette use (p:0,003). On the other hand ARP development did not adversely affect DFS and OS. In the NSCLC group, ARP developed in 5 patients who smoked more than 50 pack-year and this ratio is significantly higher than in patients who smoke less than 50 pack-year year (p:0,044) (Figure 4). In the NSCLC group, ARP developed in 5 patients and they were all heavy smokers (>50 pack-year). NSCLC patients who smoke less than 50 packyear did not develop ARP during RT. (p:0,044). (Figure 4) ARP in NSCLC patients is significantly more common in the right lung $(\mathrm{p}=0,05)$ (Figure 5) but there was no significant difference in SCLC $(p=0,1)$. There was no statistically significant difference in OS between right and left lung cancer.

Table 1. Patients' clinical characteristics

\begin{tabular}{|l|l|l|l|}
\hline Parameter & Variable & $\mathrm{n}$ & $\%$ \\
\hline Gender & Male & 65 & 90.3 \\
& Female & 7 & 9.7 \\
\hline Age & $<65$ & 28 & 40 \\
& $>65$ & 44 & 60 \\
\hline Symptom & dispne & 29 & 41 \\
& Cough & 28 & 40 \\
& Weigh & 5 & 6 \\
& loss & & \\
& Nausea & 3 & 4 \\
& Swallowin & 3 & 4 \\
& g & & \\
& difficulty & & \\
& Asymptom & 3 & 4 \\
& atic & & \\
& Other & 1 & 1 \\
\hline ECOG & 0 & 10 & 13 \\
& 1 & 50 & 68 \\
& 2 & 8 & 11 \\
& 3 & 4 & 6 \\
\hline
\end{tabular}

\begin{tabular}{|c|c|c|c|}
\hline Smoking & $\begin{array}{l}\text { Smoker } \\
\text { Non } \\
\text { smoker }\end{array}$ & $\begin{array}{l}65 \\
7\end{array}$ & $\begin{array}{l}90.3 \\
9.7\end{array}$ \\
\hline Comorbids & $\begin{array}{l}\text { Non } \\
\text { Cardiovas } \\
\text { cular } \\
\text { disease } \\
\text { Diabetes } \\
\text { Hypertensi } \\
\text { on } \\
\text { Cancer }\end{array}$ & $\begin{array}{l}3 \\
6 \\
3\end{array}$ & $\begin{array}{l}33 \\
43 \\
\\
4 \\
9 \\
4\end{array}$ \\
\hline $\begin{array}{l}\text { Disease } \\
\text { site }\end{array}$ & $\begin{array}{l}\text { Right } \\
\text { Left }\end{array}$ & $\begin{array}{r}45 \\
27 \\
\end{array}$ & $\begin{array}{r}62.5 \\
37.5 \\
\end{array}$ \\
\hline $\mathrm{T}$ & $\begin{array}{l}\mathrm{T} 1 \\
\mathrm{~T} 2 \\
\mathrm{~T} 3 \\
\mathrm{~T} 4\end{array}$ & $\begin{array}{l}5 \\
27 \\
26 \\
14 \\
\end{array}$ & $\begin{array}{l}6.9 \\
37.5 \\
36.4 \\
19.4 \\
\end{array}$ \\
\hline $\mathrm{N}$ & $\begin{array}{l}\text { N0 } \\
\text { N1 } \\
\text { N2 } \\
\text { N3 }\end{array}$ & $\begin{array}{l}9 \\
8 \\
43 \\
12 \\
\end{array}$ & $\begin{array}{l}12.5 \\
11.1 \\
59.7 \\
16.7\end{array}$ \\
\hline $\mathrm{M}$ & $\begin{array}{l}\text { M0 } \\
\text { M1 }\end{array}$ & $\begin{array}{l}63 \\
9 \\
\end{array}$ & $\begin{array}{l}87.5 \\
12.5 \\
\end{array}$ \\
\hline Patoloji & $\begin{array}{l}\text { SCLC } \\
\text { Adenocarc } \\
\text { inoma } \\
\text { SCC } \\
\text { Others } \\
\end{array}$ & $\begin{array}{l}21 \\
11 \\
38 \\
2 \\
\end{array}$ & $\begin{array}{l}29.2 \\
15.3 \\
\\
52.8 \\
2.8 \\
\end{array}$ \\
\hline $\begin{array}{l}\text { Chemother } \\
\text { apy }\end{array}$ & + & $\begin{array}{r}45 \\
27 \\
\end{array}$ & $\begin{array}{r}62.5 \\
37.5 \\
\end{array}$ \\
\hline
\end{tabular}

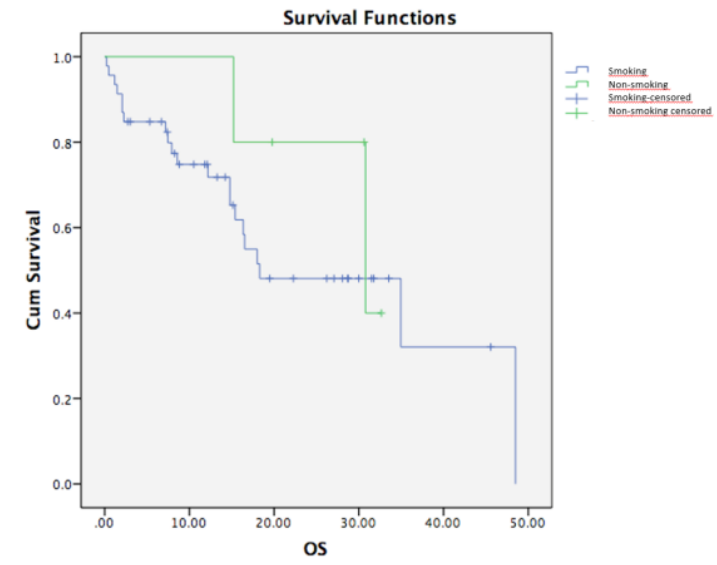

Figure 1.Survival curve of smoker and nonsmoker 


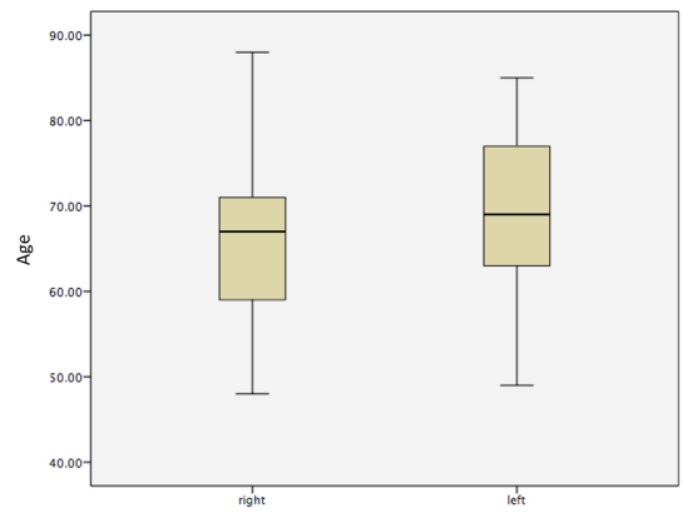

Figure 2. The left lung cancer is developed in older age than right lung.

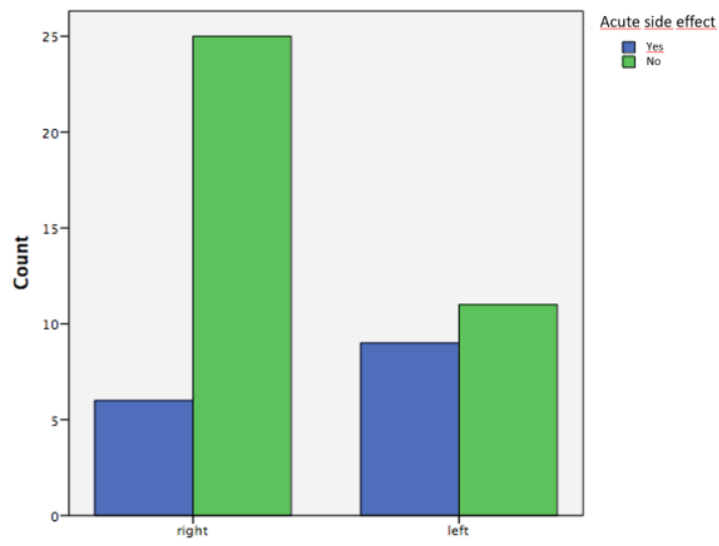

Figure 3. Acute side effects in NSCLC are significantly more common in the right lung.

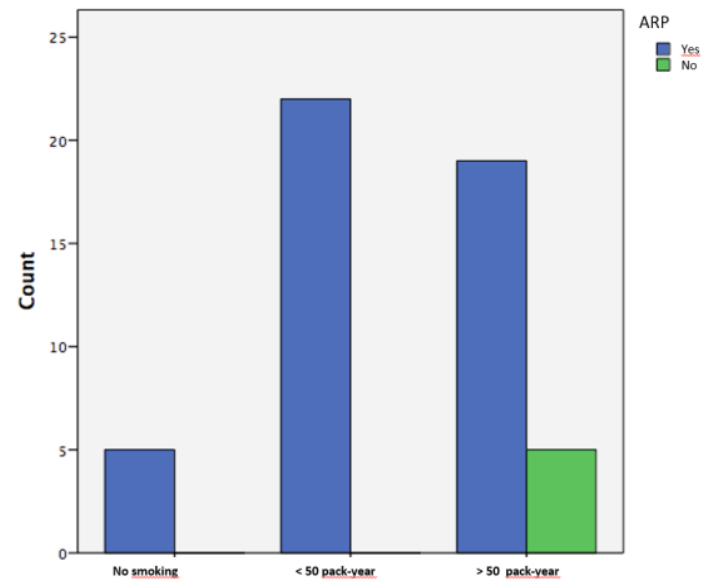

Figure 4. Patients who smoked $>50$ pack-year developed ARP in NSCLC group ().

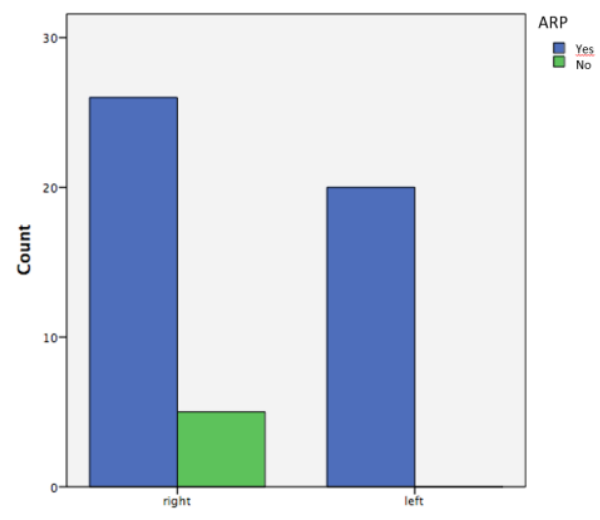

Figure 5. ARP is more common in the right lung.

\section{DISCUSSION}

Similar to previous studies, lung cancer was more common in the right side. In smokers, right-sided tumors were more common than left-sided tumors. In addition, acute side effects were seen more frequently on the right NSCLC patients during RT. The risk of developing ARP significantly increases in right sided NSCLC patients with >50 pack-year tobacco use. However, these differences do not significantly affect the overall survival of patients in our series.

In the contact hypothesis, it is argued that the right lung is exposed to more carcinogens. Because of these exposures, right side-lung cancer occurs more often than left lung (2).

Sahmoun et. al evaluated the anatomical distribution of SCLC and they found that right upper lob is significantly most common side and they also observed that right localization is associated with worse prognosis (14). The pathophysiology behind the predominance of the right side or upper location of lung cancer is unclear. The lower lobes are wider than upper lobes and have more air circulation. Upper lobes have higher PO2 levels and numerous infections usually occur in the upper lobes and cause an anatomic physiological defect (14). Additionally, studies stated that infections especially with Mycobacterium tuberculosis is associated with higher risk of lung cancer (8). Right lung predilection of lung cancer is confirmed by other studies $(14,15)$. Similar results were observed in our study. Approximately $2 / 3$ of 
the patients were localized on the right side. However, OS did not differ between groups. The bronchial structures can be grouped into 4 section based on diameter: (T) trachea; (MI) mainstem bronchus and intermediate bronchus; (UML) upper-, middle-, and lower- lobe bronchi; and (SB) segmental bronchi. The trachea separates into right and left mainbronchi. The right main bronchus is in reaches more vertical angle, its diameter is approximately $2 \mathrm{~cm}$. The left main bronchi have a more oblique angle and it is 4 to $6 \mathrm{~cm}$ diameter $(5,6)$. So, carcinogens may be thought to be localized to the right more easily than left because the right bronchi are steeper and it nearly contiguous with the trachea (2). Additionally, right lung has the larger volume because of heart localization, it may also affect this higher prevalence (10).

Not only anatomic but also histological structure may cause this difference. The tracheobronchial airways are in the gas exchange area. The bronchi consist of mucus and basal cells in the epithelium, mucosal glands in the interstitium, and a significant amount of cartilage in the interstitial spaces. Distal bronchioles have a thinner wall without cartilage. The tracheobronchial airways occupy approximately $1 \%$ in human (6).

The main structure of the differentiated human airway epithelium is pseudostratified and polarized epithelium which have cilia. Clara cells, basal cells, and goblet cells are also been (7). Ciliated epithelial cells are played important role mucociliary clearance and host immune defence against for both of pathogens and carcinogens. Each ciliated cell has approximately 300 motile cilia and they are cleared up mucus and foreign bodies (8). Basal cells are seated on the basement membrane and express some cytokeratins and the transcription factor TP63. Clara cells are secreted antiinflammatory and immune-modulatory proteins and goblet cells expresses mucus (7).

Smoking causes basal and goblet cell differentiation and reduced ciliated cell number (7). Smoking can cause epithelial regeneration which producing to extreme epithelial proliferation, squamous or mucous cell metaplasia, hypersecretion for some chemokines, submucosal thickening and inflammation with neutrophilic and mononuclear inflammatory cells, goblet cell hyperplasia, increasing mucus secretions from goblets cells $(9,10,11)$. Mucus is the first physical barrier for inhaled organic or inorganics materials (10). Finally, mucociliary transport is deteriorated, and increasing mucus is facilitated for bacterial colonization and accumulation of carcinogens, dust or pathogens (10). Lung cancers occur after a series of sequential abnormal changes (preneoplastic or precursor lesions) in the respirator airway tract (13).

In our series, smokers had significantly high incidence of right-side NSCLC, but they don't have a side tendency for SCLC. However, the number of patients who do not smoke in SCLC was only 2.

Smoking also increases side effects in cancer therapies (18). Acute side effects, especially ARP, are more prevalent in the right lung tumors. This results also support that, the right side is exposed to carcinogenesis at a higher rate than the left.

Additionally, in our study left side lung cancer was more frequent than right in older ages, it can be considered as a condition supporting the contact hypothesis. If the left lung cancer may occur, it takes longer time due to less exposure.

There are some limitations in this study. First, data are evaluated retrospectively. Second, there are not enough number of patients in SCLC, women and non-smoker subgroups which devalue statistical analysis. Third, the smoking cessation data is lacking. The effect of smoking cessation on outcomes could not be assessed. Last, just right and left evaluation has done. Detailed lob evaluation were not performed. The effect of the localization on the side effect and the outcome, should be considered in wider studies. Depending on the significance of the results, treatment type and follow-up frequency could be changed.

\section{CONCLUSION}

LC is often seen in the right lung. Similarly, acute pulmonary side effects are also more frequently observed in the right side. Risk of developing ARP is significantly higher in patients with a history of $>50$ pack-year cigarette smoking. There is no statistically difference survival difference between right and left lung cancer. 
Conflict of Interest: All authors certify that they have no affiliations with or involvement in any organization or entity with any financial interest (such as honoraria; educational grants; participation in speakers' bureaus; membership, employment, consultancies, stock ownership, or other equity interest; and expert testimony or patent-licensing arrangements), or non-financial interest (such as personal or professional relationships, affiliations, knowledge or beliefs) in the subject matter or materials discussed in this manuscript.

\section{REFERENCES}

1. Bogart JA. Thoracic Neoplasms Overview In: Gunderson LL, Tepper JE, editors. Clinical Radiation Oncology. Philedelphia, USA. 2016; 4th Eds ;788-798.

2. Parkash O. Lung cancer. A statistical study based on autopsy data from 1928 to 1972 . Respiration. 1977;34(5):295-304

3. Fréchette E, Deslauriers J. Surgical Anatomy of the Bronchial Tree and Pulmonary Artery. Semin Thorac Cardiovasc Surg. 2006; 18:77-84.

4. Tatsanakanjanakorn W, Suetrong S. Do Times until Treatment for Foreign Body Aspiration Relate to Complications?. International Journal of Otolaryngology. 2016; 28: 316-314.

5. Duijm M, Schillemans W, Aerts JG, Heijmen B, Nuyttens JJ. Dose and Volume of the Irradiated Main Bronchi and Related Side Effects in the Treatment of Central Lung Tumors With Stereotactic Radiotherapy. Semin Radiat Oncol. 2016;26(2):140-148.

6. Hyde DM, Hamid Q, Irvin CG. Anatomy, pathology, and physiology of the tracheobronchial tree: Emphasis on the distal airways. J Allergy Clin Immunol 2009;124: 72-77.

7. Schamberger AC, Staab-Weijnitz CA, Mise-Racek $\mathrm{N}$, Eickelberg O. Cigarette smoke alters primary human bronchial epithelial cell differentiation at the air-liquid interface. Sci Rep. 2015; 5:8163.
8. Couraud S, Zalcman G, Milleron B, Morin F, Souquet PJ. Lung cancer in never smokers - A review. European Journal of Cancer. 2012;48:1299- 1311.

9. Broekema M, Hacken NHT, Volbeda F, Lodewijk ME, Hylkema MN, Postma DS, Wim Timens W. Airway Epithelial Changes in Smokers but Not in Ex-Smokers with Asthma. Am J Respir Crit Care Med. 2009;180:1170-1178

10. Thorley AJ, Tetley TD. Pulmonary epithelium, cigarette smoke, and chronic obstructive pulmonary disease. Int $\mathrm{J}$ Chron Obstruct Pulmon Dis. 2007;2(4):409-428.

11. Tamashiro E, Cohen NA, Palmer JN, Lima WT, Effects of cigarette smoking on the respiratory epithelium and its role in the pathogenesis of chronic rhinosinusitis. Braz J Otorhinolaryngol. 2009:75(6):903-907.

13. Wistuba II, Mao L, Gazdar AF. Smoking molecular damage in bronchial epithelium. Oncogene. 2002;21(48):7298-7306.

14. Sahmoun AE, Case LD, Santoro TJ, Schwartz GG. Anatomical distribution of small cell lung cancer: effects of lobe and gender on brain metastasis and survival. Anticancer Res. 2005;25(2A):1101-1108.

15. Sahmoun AE, Case LD, Chavour $S$, Kareem $S$, Schwartz GG. Hypertension and risk of brain metastasis from small cell lung cancer: a retrospective follow-up study. Anticancer Res. 2004;24(5):3115-3120.

16. Firat S, Byhardt RW, Gore E. Comorbidity and Karnofksy performance score are independent prognostic factors in stage III non-small-cell lung cancer: an institutional analysis of patients treated on four RTOG studies. Radiation Therapy Oncology Group. Int J Radiat Oncol Biol Phys. $2002 ; 54(2): 357-364$.

17. Firat $S$, Bousamra $M$, Gore $E$, Byhardt RW. Comorbidity and KPS are independent prognostic factors in stage I non-small-cell lung cancer. Int $\mathrm{J}$ Radiat Oncol Biol Phys. 2002;52(4):1047-1057.

18. Peppone LJ, Mustian KM, Morrow GR, Dozier AM, Ossip DJ, Janelsins MC, Sprod LK, McIntosh S. The effect of cigarette smoking on cancer treatment-related side effects. Oncologist 2011;16(12):1784-1792. 